\title{
Environmental factors affecting mayfly assemblages in tufa-depositing habitats of the Dinaric Karst
}

\author{
Marina Vilenica ${ }^{1, *}$, Vlatka Mičetić Stanković ${ }^{2}$, Michel Sartori ${ }^{3}$, Mladen Kučinić ${ }^{4}$ and \\ Zlatko Mihaljević ${ }^{4}$ \\ ${ }^{1}$ University of Zagreb, Faculty of Teacher Education, Trg Matice hrvatske 12, 44250 Petrinja, Croatia \\ ${ }^{2}$ Croatian Natural History Museum, Demetrova 1, 10000 Zagreb, Croatia \\ ${ }^{3}$ Museum of Zoology, Place de la Riponne 6, 1005 Lausanne, Switzerland \\ ${ }^{4}$ University of Zagreb, Faculty of Science, Rooseveltov trg 6, 10000 Zagreb, Croatia
}

\begin{abstract}
Remarkably, unlike other parts of Europe, the ecology of mayflies in the southeastern regions is still poorly known. Here we present the first comprehensive study of Ephemeroptera in the tufa-depositing habitats of the Dinaric Karst. The study was conducted in Plitvice Lakes National Park monthly during a one-year period (2007-2008) in different types of habitats (springs, streams, mountainous rivers, tufa barriers). The aims of the study were to determine mayfly composition, abundance, spatial distribution and habitat preferences, and to examine the environmental factors important for the structuring of mayfly assemblages in Plitvice Lakes National Park. The mayfly fauna of tufa-depositing habitats was composed of 14 species (20 taxa). Water temperature, $\mathrm{pH}$ and ammonium concentration were the most important environmental variables explaining mayfly assemblages. Mayfly assemblages grouped according to habitat type. Generally, the most favourable habitat type was mountainous stream, tufa barriers were less favourable, and the least favourable were springs. Our results confirmed that mayflies are a powerful tool as descriptors of their environment, as the presence or absence of certain mayflies was strongly influenced by physico-chemical water properties.
\end{abstract}

Keywords: case study / ecology / abiotic factors / Ephemeroptera / Southeast Europe

Résumé - Facteurs environnementaux influençant la composition des éphémères dans les tufières du Karst Dinarique. De manière surprenante, et contrairement à d'autres parties de l'Europe, l'écologie des éphémères de la zone sud orientale est encore largement inconnue. Dans ce travail, nous présentons la première étude approfondie des éphémères habitant des tufières. L'étude a été menée au Parc National de Plitvice Lacs durant un an (2007-2008) dans différents types d'habitats (sources, ruisseaux, rivières montagneuses, barrières de tuf). Les objectifs de cette étude étaient de déterminer la composition, l'abondance, la distribution spatiale et les habitats préférentiels des éphémères, d'une part, et d'examiner quels facteurs environnementaux étaient responsables de leur structuration, d'autre part. La faune des éphémères des tufières est composée de 14 espèces (20 taxons). La température de l'eau, le $\mathrm{pH}$ et la concentration en ammonium sont les variables environnementales les plus importantes qui expliquent la composition des éphémères. Celle-ci est fonction des types d'habitats. De manière générale, le type d'habitat le plus favorable est celui représenté par les ruisseaux, suivi par les barrières de tuf, les sources étant les moins favorables. Les résultats confirment la puissante capacité des éphémères à décrire leur environnement, puisque la présence ou l'absence de certaines espèces est fortement influencée par les propriétés physico-chimiques de l'eau.

Mots-clés : étude de cas / écologie / facteurs abiotiques / Ephemeroptera / sud-est de l'Europe

\footnotetext{
* Corresponding author: marina.vilenica@gmail.com
} 


\section{Introduction}

Ephemeroptera (mayflies) is an order of aquatic insects that plays an important role in running and standing waters, representing a very large proportion of the aquatic ecosystem biomass (Brittain and Sartori, 2003; Bauernfeind and Soldán, 2012).

Water temperature, dissolved oxygen concentration, nutrients, water velocity and substrate type are the most important natural environmental factors driving freshwater communities, including mayflies (Giller and Malmqvist, 1998; Moog, 2002; Allan and Castillo, 2007; Choudhary et al., 2014). Stream insects often show longitudinal zonation along habitats following the downstream gradient in physicochemical water properties (Vannote et al., 1980; Giller and Malmqvist, 1998; Bauernfeind and Humpesch, 2001). The majority of mayfly species prefer the meta- and hyporhithral sections (upper reaches) of the fast-flowing streams and rivers, and ecologically intact large potamal rivers (Bauernfeind and Moog, 2000; Bauernfeind and Soldán, 2012). On the other hand, crenal (spring) sections of streams, high mountains and metapotamal river sections (lower reaches) usually have low mayfly species diversity (Bauernfeind and Soldán, 2012).

The longitudinal succession of macroinvertebrate communities, including mayflies, reflects the temperature regime of a river, the differences in other environmental factors, but also the changes in food webs (Giller and Malmqvist, 1998; Moog, 2002; Schmidt-Kloiber and Hering, 2015). Consequently, changes in mayfly assemblages are often used as an important parameter to detect and assess temperature increases induced by climate change, or to assess river degradation (e.g. hydromorphological changes) and stress intensity (SchmidtKloiber and Hering, 2015).

Karst is a set of morphological, hydrological and hydrogeological terrain features built of water-soluble rock. Due to anthropogenic pressure and the specific hydrology and soil morphology (Sánchez-Fernández et al., 2004), karst habitats are particularly endangered. These fragile ecosystems are inhabited by numerous rare and endangered species (Bonacci et al., 2008; Bonacci, 2009). The karstification process has resulted in a mosaic of climatic and environmental conditions with diverse physiographic traits. Geographical isolation, local influences of climate and altitude and high habitat heterogeneity may have favoured the maintenance of a high level of speciation, and a high number of discontinuous populations of phylogenetically distinct origin (Bonacci et al., 2008; Previšić et al., 2009, 2014; Ivković and Plant, 2015). The Dinaric Mountains are the largest continuous karst landscape in Europe (Mihevc et al., 2010), extending over approximately $60,000 \mathrm{~km}^{2}$, with an extremely complicated hydrological network (Bonacci and Jelin, 1988; Bonacci et al., 2013). The mountain range lies along the western Balkan Peninsula, stretching in a north-south direction from northeastern Italy to Albania (Bonacci, 2009). Freshwater karst habitats are characterized by an exceptional phenomenon: secondary calcium-carbonate deposition - tufa. Tufa is a product of the physico-chemical characteristics of water, geological bed and the present biota. The biological component is a crucial factor in the genesis and maintenance of cascade lake systems with tufa barriers (barrage lakes), such as Plitvice Lakes National Park (Srdoč, 1985).
Faunistic surveys and ecological studies involving various aquatic insect groups were recently conducted in the Dinaric Karst area, e.g. stoneflies (Popijač and Sivec, 2009), caddisflies (Previšić et al., 2007; Šemnički et al., 2012), blackflies (Ivković et al., 2013a), aquatic dance flies (Ivković et al., 2013b) and riffle beetles (Mičetić Stanković et al., 2015). However, the ecological preferences of mayfly assemblages in this region are still poorly known (e.g. Hrovat et al., 2009; Vilenica et al., 2016a, b). Matoničkin and Pavletić (1961, 1967); Habdija et al. (1994) and Habdija et al. (2004) investigated mayflies only sporadically as a part of invertebrate benthic communities. Moreover, most of the previous identifications are ambiguous, as the identification tools were not cited or current revision of sampled material is not possible.

Therefore, the main goals of this study were to

- determine the composition, abundance and spatial distribution of mayflies;

- determine the mayfly habitat preferences and

- examine which environmental factors are important in structuring mayfly assemblages in the selected tufadepositing karst freshwater ecosystem of Plitvice Lakes National Park.

\section{Material and methods}

\subsection{Study area}

Plitvice Lakes National Park is located in the Dinaric Karst region in Croatia. The Plitvice Lakes' barrage lake system consists of 16 oligotrophic, dimictic and fluvial lakes divided and interconnected by tufa-depositing barriers (Fig. 1). After the confluence, the small mountainous rivers Bijela rijeka and Crna rijeka form the Matica river, the main surface-water supplier of the lakes (Stilinović and Božičević, 1998).

The climate is transitive, moderately mountainous (Šikić, 2007). The main rainfall occurs in autumn and winter, while the air temperature during the winter drops to $-25^{\circ} \mathrm{C}$ and during the summer rises above $30^{\circ} \mathrm{C}$ (Makjanić, 1958). The area is rich in a range of karst habitat types (Stilinović and Božičević, 1998) and well known for its high endemism, especially in freshwater (Bãnãrescu, 2004), which is why Plitvice Lakes National Park (NP) was designated as a UNESCO world natural heritage site in 1979 (Stilinović and Božičević, 1998).

Sampling was conducted in various habitats at 10 study sites. According to their altitude and habitat type, lotic habitats were classified into four categories (Fig. 1, Tab. 1):

- Rheocrene springs of upper lotic habitats (small mountainous rivers): spring of the Bijela rijeka river (elevation $720 \mathrm{~m}$ ) (IBR) and spring of the Crna rijeka river (675 m) (ICR).

- Downstream sections of upper lotic habitats (small mountainous rivers): upper reaches of the Bijela rijeka river $(716 \mathrm{~m})$ (SBR), middle reaches of the Crna rijeka river $(670 \mathrm{~m})(\mathrm{SCR})$ and lower reaches of the Crna rijeka river $(665 \mathrm{~m})(\mathrm{CM})$.

- Three tufa barriers, situated between upper and lower lotic habitats: Tufa barrier Labudovac $(630 \mathrm{~m})$ (LB), Tufa barrier Kozjak-Milanovac (545 m) (KM) and Tufa barrier Novakovića Brod (505 m) (NOB).

- Tufa-depositing lower lotic habitats at the end of the cascade system represented by downstream sections of the canyon type mountainous stream Plitvica stream (555 m) (PP) and mid-altitude large river Korana river (390 m) (KR). 

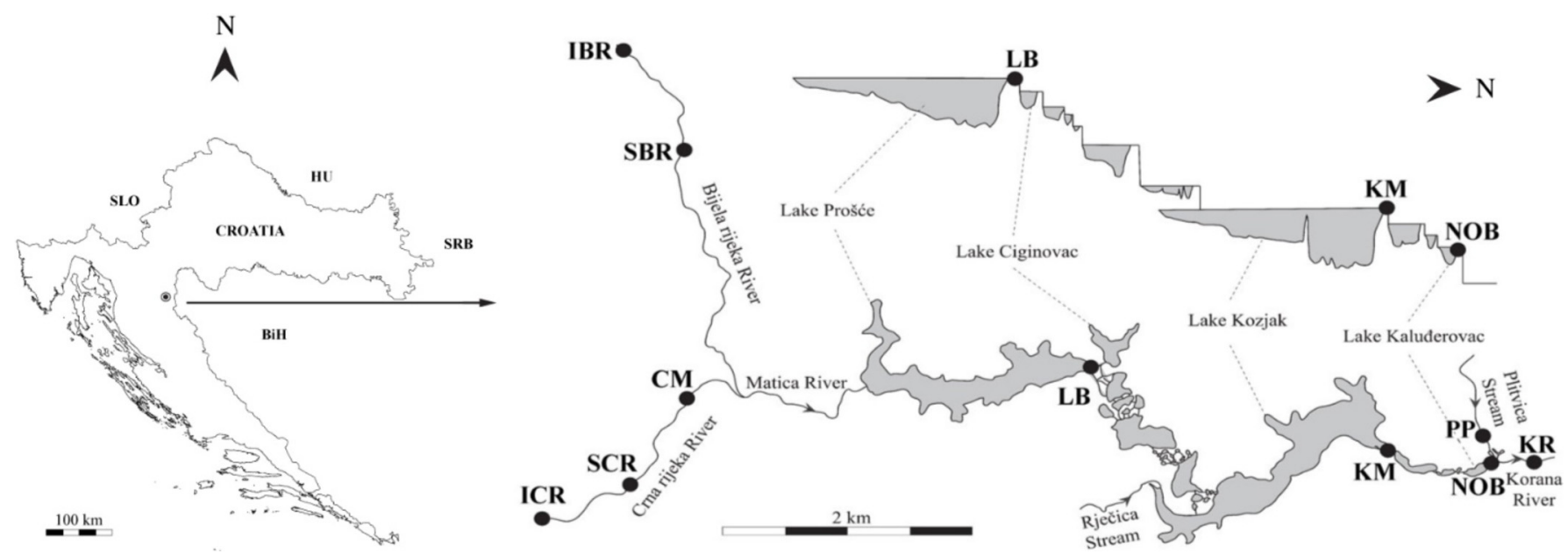

Fig. 1. Location of Plitvice Lakes NP in Croatia and position of 10 study sites in Plitvice Lakes NP. Legend: IBR $=$ Bijela rijeka river spring, $\mathrm{SBR}=$ Bijela rijeka river upper reaches, $\mathrm{ICR}=\mathrm{Crna}$ rijeka river spring, $\mathrm{SCR}=$ Crna rijeka river middle reaches, $\mathrm{CM}=\mathrm{Crna}$ rijeka river lower reaches, $\mathrm{KR}=$ Korana river, $\mathrm{PP}=$ Plitvica stream, $\mathrm{KM}=$ Tufa barrier Kozjak-Milanovac, $\mathrm{LB}=$ Tufa barrier Labudovac, $\mathrm{NOB}=$ Tufa barrier Novakovića Brod.

\subsection{Mayfly sampling}

Mayfly larvae were sampled monthly from February 2007 to February 2008 with other macroinvertebrates using a Surber sampler $\left(0.1 \mathrm{~m}^{2}\right.$ surface area and $0.5 \mathrm{~mm}$ mesh size $)$. In the $\mathrm{CM}$, a D-frame hand net (with $0.5 \mathrm{~mm}$ mesh size) was used. Every month, at each site, three samples were taken, with the exception of the IBR, where four samples were taken. Samples were conserved in $80 \%$ ethanol.

\subsection{Environmental factors}

Physico-chemical water properties were measured monthly at each study site (Tab. 1): oxygen concentration, oxygen saturation, water temperature (using the oximeter WTW Oxi 330/SET), $\mathrm{pH}$ (using the pH-meter WTW ph 330), conductivity (with the conductivity meter WTW LF 330), alkalinity (by titration with $0.1 \mathrm{M} \mathrm{HCl}$ ), water velocity (with P-670-M velocimeter), water depth (with handheld meter) and nutrients (ammonium by HRN ISO 70-3:1998 method, nitrates and nitrites by HRN ISO 7890-3:2001 method and orthophosphates by HRN ISO 6878:2001 method). Water velocity and water depth were measured at each sampled microhabitat. Altitude and distance from the springs were determined for each study site. Geographical coordinates were read using a GPS Garmin Oregon 550, and subsequently processed in ArcGIS software.

\subsection{Data analysis}

For all data, the Shapiro-Wilk normality test was performed. All mayfly data were log-transformed prior to analyses.

In order to determine differences in physico-chemical water properties between habitat types, one-way ANOVA for water velocity and Kruskal-Wallis $H$ test with multiple comparisons test for other environmental factors were applied.
Non-metric multidimensional scaling analysis (NMDS) was applied to show similarities in the composition of mayfly assemblages among study sites using the Bray-Curtis similarity index. The results of the hierarchical cluster analysis are superimposed on NMDS ordination.

The relationship of mayflies to environmental factors were analysed from various aspects: (i) Kruskal-Wallis $H$ test with multiple comparisons test and indicator value method (IndVal) were used to determine the preference of each recorded taxon for a certain habitat type, with Monte Carlo permutation test (4999 permutations) and threshold value of the proportion determining the characteristic indicator taxa of 55\% (Dufrêne and Legendre, 1997); (ii) Spearman's rank correlation coefficient $(R)$ for analysis of the relationship of mayfly assemblages (number of individuals, number of taxa) and each of the recorded species with physico-chemical water properties; (iii) Canonical correspondence analysis (CCA) with Monte Carlo permutation test of significance (with 999 permutations) was used for identification and measurement of the mayfly associations and environmental conditions. The CCA analysis included 20 taxa and 9 physico-chemical water parameters. Prior to the CCA analysis, the full draftsman's plot excluded orthophosphates and nitrites.

Analyses were performed in Statistica, version 10.0 (Statsoft Inc., Tulsa, PC-ord ver. 5.0), Primer 6 software package (Clarke and Gorley, 2006) and CANOCO for Windows (ver. 4.02) (Ter Braak and Smilauer, 1998).

\section{Results}

\subsection{Environmental factors}

Kruskal-Wallis and multiple comparisons of mean ranks for all groups separated the four habitat types (springs, upper lotic habitats, tufa barriers and lower lotic habitats), based on their physico-chemical water properties (Tabs. 1 and 2). 
M. Vilenica et al.: Knowl. Manag. Aquat. Ecosyst. 2017, 418, 14

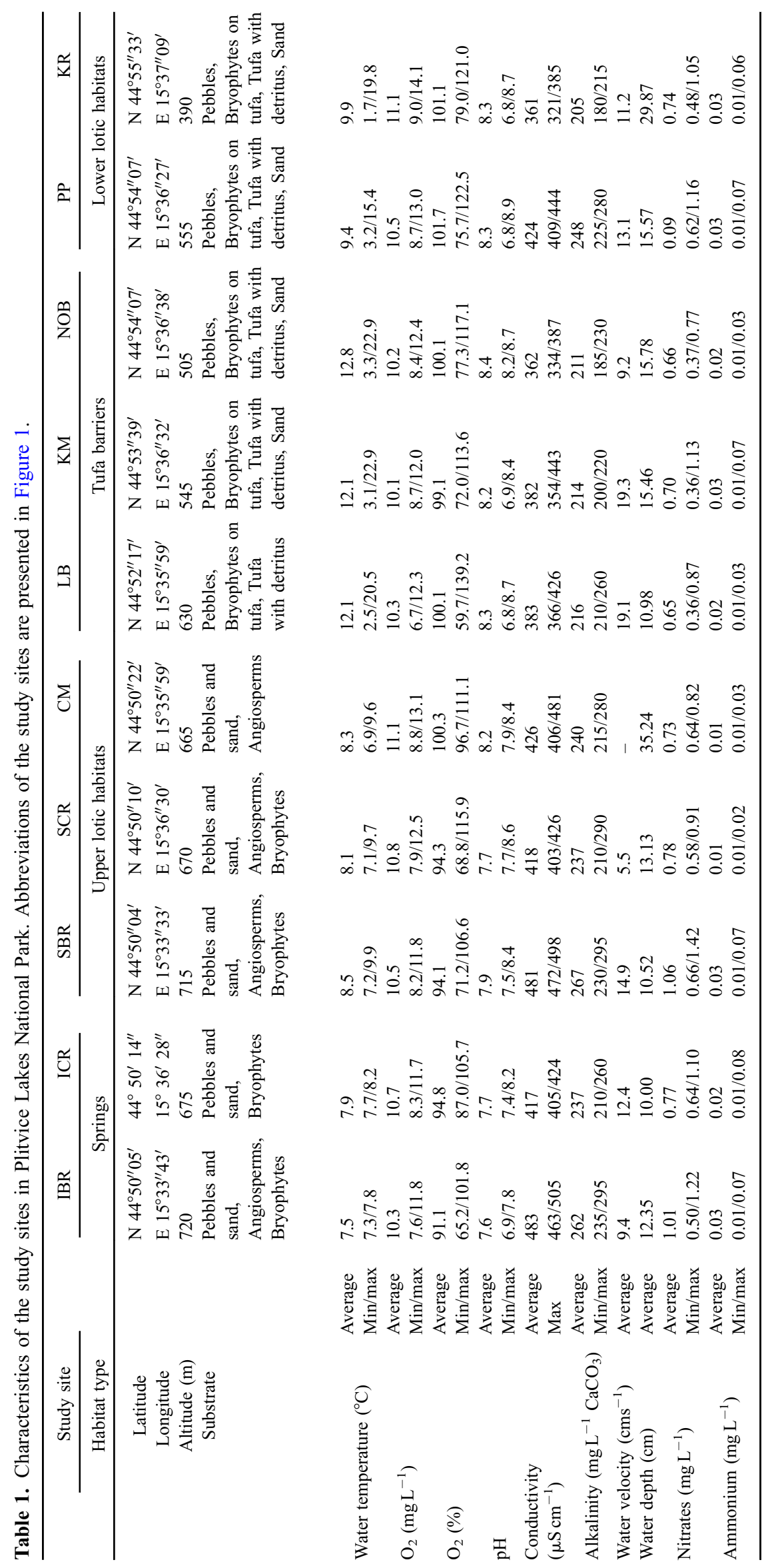


Table 2. Significant differences in physico-chemical water properties between habitat types in Plitvice Lakes NP based on Kruskal-Wallis $H$ test with multiple comparisons test. Sample size $(N)=31,{ }^{* * *} p<0.001,{ }^{* *} p<0.01, * p<0.05$.

\begin{tabular}{|c|c|c|c|}
\hline Differences between habitat types & Physico-chemical water parameter & $H$ & $p$ \\
\hline \multirow[t]{4}{*}{ Tufa barriers and springs } & Water temperature & 27.25 & $* * *$ \\
\hline & $\mathrm{pH}$ & 20.87 & $* * *$ \\
\hline & Conductivity & 14.70 & $* *$ \\
\hline & Nitrates & 16.90 & $* *$ \\
\hline \multirow[t]{5}{*}{ Tufa barriers and upper lotic habitats } & Oxygen concentration & 22.32 & $* * *$ \\
\hline & Alkalinity & 12.58 & $* *$ \\
\hline & Water temperature & 27.25 & $* *$ \\
\hline & Nitrates & 16.90 & $* *$ \\
\hline & Conductivity & 14.70 & $*$ \\
\hline Tufa barriers and lower lotic habitats & Oxygen concentration & 22.32 & $* *$ \\
\hline \multirow[t]{2}{*}{ Springs and lower lotic habitats } & $\mathrm{pH}$ & 20.87 & $* *$ \\
\hline & Water temperature & 27.25 & $*$ \\
\hline
\end{tabular}

\subsection{Population aspects and relation of mayflies to environmental factors}

A total of 14 mayfly species (20 taxa), belonging to 13 genera and 7 families, were recorded. Early instars or damaged specimens were identified to the genus or family level (six taxa) (Tab. 3). Springs and one tufa barrier had the lowest number (four) of mayfly species (Tab. 3). The highest diversities and abundances were recorded in the lower lotic habitats, especially at the site Plitvica stream (PP) (Tab. 3). Baetis rhodani (Pictet, 1843) and B. cf. nubecularis (Eaton, 1989) were the most widely distributed species, while Serratella ignita (Poda, 1761) was the most abundant. On the contrary, Procloeon pennulatum (Eaton, 1870) was the rarest recorded species (Tab. 3).

NMDS analysis (Fig. 2a and b) showed clustering of the sites according to habitat type. Sites located in the upper lotic habitats (IBR, SBR and SCR) were clearly separated from the tufa barriers (LB, NOB and KM) and lower lotic habitats (PP and KR), which clustered together. A single study site located in the downstream sections of the upper lotic habitats (CM) clustered with the lower lotic habitats and tufa barriers.

Preferences for a certain habitat type was significant for four mayfly species: Rhithrogena braaschi Jacob, 1974 (IndVal=62.3, $p<0.05$ ) for upper lotic habitats; Caenis horaria (Linnaeus, 1758) (IndVal $=55.6, p<0.01)$ for tufa barriers and Centroptilum luteolum (Müller, 1776) (IndVal= 58.6, $p<0.05$ ) and S. ignita (IndVal =99.7, $p<0.001$ ) for lower lotic habitats.

Significant differences between abundances were recorded for two mayfly species. According to Kruskal-Wallis $\mathrm{H}$ test and multiple comparisons of mean ranks for all groups, abundances of $R h$. braaschi were significantly different between the tufa barriers and springs $(p<0.05)$, and between the tufa barriers and upper lotic habitats $(p<0.05)$, as this species was absent from the tufa barriers and was most abundant in the upper lotic habitats (Tab. 3). Abundances of S. ignita strongly differed between the lower lotic habitats and other habitat types: springs $(p<0.01)$, tufa barriers $(p<0.01)$ and upper lotic habitats $(p<0.05)$. The species was absent from the springs, present in very low numbers in tufa barriers and upper lotic habitats and highly abundant in the lower lotic habitats (Tab. 3).

The eigenvalues for the first two CCA axes (Fig. 3) were 0.373 and 0.224 and accounted for $53.2 \%$ of the variability in species-environment relations, while the eigenvalues accounted for $80.1 \%$ of the overall variability. The Monte Carlo permutation test showed that the species-environment ordination was statistically significant (first axis: $F$-ratio $=$ 4.876, $p=0.002 ; \quad$ overall: trace $=1.122, \quad F=3.048$ and $p=0.002$ ), indicating that mayfly assemblages were significantly related to the tested set of environmental variables. Axis 1 was related to water temperature $(R=0.646)$ and $\mathrm{pH}$ $(R=0.632)$ and Axis 2 to ammonium concentrations $(R=0.690)$, indicating that these were the most important parameters in explaining patterns of the mayfly assemblages.

The number of mayfly taxa $(\mathrm{S})$ was positively correlated with conductivity $(R=0.21, p<0.001)$, alkalinity $(R=0.19$, $p<0.001)$ and the concentration of nitrate ions $(R=0.14$, $p<0.01)$. The number of mayfly individuals $(N)$ was positively correlated with conductivity $(R=0.18, p<0.001)$, alkalinity $(R=0.16, p<0.01)$, concentrations of ammonium $(R=0.13, p<0.01)$ and nitrate ions $(R=0.19, p<0.05)$, water temperature $(R=0.11, p<0.05)$ and water velocity $(R=0.12$, $p<0.05)$. A negative correlation was determined between mayfly abundance and water depth $(R=-0.17, p<0.001)$. Significant correlations with physico-chemical water properties were recorded for 13 species (Tab. 4).

\section{Discussion}

Aquatic organisms in Plitvice Lakes NP are confronted with specific environmental conditions, such as low nutrient availability, low water temperature and high alkalinity, which 
Table 3. Mayfly abundance (shown as a number of individuals per $\mathrm{m}^{2}$ ) and distribution in Plitvice Lakes NP: (a) springs and upper lotic habitats, (b) tufa barriers and lower lotic habitats. Abbreviations of the study sites are presented in Figure 1.

\begin{tabular}{ll}
\hline Habitat type & \multicolumn{1}{c}{ Springs } \\
\cline { 2 - 2 } Mayfly taxa/Microhabitat & IBR1 IBR2 IBR3 IBR4 ICR1 ICR2 ICR3 SBR1 SBR2 SBR3 SCR1 SCR2 SCR3 CM1 CM2 CM3 \\
\hline
\end{tabular}

(a) Springs and upper lotic habitats.

Baetidae juv.

Alainites muticus (Linnaeus, 1758)

Baetis sp. juv.

Baetis cf. nubecularis (Eaton, 1898)

Baetis rhodani (Pictet, 1843)

Centroptilum luteolum (Müller, 1776)

Procloeon pennulatum (Eaton, 1870)

Caenis sp. juv.

Caenis horaria (Linnaeus, 1758)

Ephemerellidae juv.

Serratella ignita (Poda, 1761)

Torleya major (Klapalek, 1905)

Ephemera danica Müller, 1764

Heptageniidae juv.

Ecdyonurus submontanus Landa, 1969

Rhithrogena braaschi Jacob, 1974

Leptophlebiidae juv.

Habrophlebia lauta Eaton, 1884

Paraleptophlebia submarginata

(Stephens, 1835)

Siphlonurus croaticus Ulmer, 1920
304368

$\begin{array}{ll}0 & 48\end{array}$

$32 \quad 144$

$\begin{array}{rr}16 & 64\end{array}$

528416

00

$\begin{array}{ll}0 & 0\end{array}$

$\begin{array}{ll}0 & 0\end{array}$

$\begin{array}{ll}0 & 0\end{array}$

0

0

0

$\begin{array}{ll}0 & 0\end{array}$

00

$\begin{array}{rr}0 & 0 \\ 1424 & 112\end{array}$

1424112

$\begin{array}{ll}0 & 0 \\ 0 & 0 \\ 0 & 0\end{array}$

$\begin{array}{rrrrrr}510 & 224 & 0 & 5049 & 0 & 536 \\ 0 & 96 & 0 & 0 & 0 \\ 918 & 16 & 384 & 3519 & 96 & 35 \\ 275 & 16 & 0 & 3876 & 240 & \\ 459 & 672 & 464 & 1632 & 416 & 240\end{array}$

$\begin{array}{rrrrrr}5360 & 2880 & 7191 & 448 & 5967 & 0 \\ 0 & 0 & 0 & 0 & 0 & 0 \\ 352 & 1952 & 1683 & 128 & 4182 & 0 \\ 400 & 176 & 2448 & 544 & 3468 & 0 \\ 2400 & 1584 & 3366 & 960 & 969 & 16 \\ 0 & 0 & 0 & 0 & 0 & 0 \\ 0 & 0 & 0 & 0 & 0 & 0 \\ 0 & 0 & 0 & 0 & 0 & 0 \\ 0 & 0 & 0 & 0 & 0 & 0 \\ 0 & 0 & 0 & 0 & 0 & 0 \\ 0 & 0 & 0 & 0 & 0 & 0 \\ 0 & 0 & 0 & 0 & 0 & 0 \\ 0 & 0 & 0 & 16 & 0 & 0 \\ 0 & 0 & 0 & 2896 & 357 & 16 \\ 0 & 0 & 0 & 48 & 0 & 0 \\ 12272 & 592 & 612 & 9632 & 306 & 0 \\ 0 & 0 & 0 & 0 & 0 & 0 \\ 0 & 0 & 0 & 0 & 0 & 0 \\ 0 & 0 & 0 & 0 & 0 & 0\end{array}$

$\begin{array}{lll}0 & 80 & 0\end{array}$

$\begin{array}{lll}0 & 32 & 0\end{array}$

$\begin{array}{lll}112 & 0 & 0\end{array}$

$\begin{array}{lll}0 & 0 & 0\end{array}$

$880 \quad 256 \quad 32$

$\begin{array}{lll}0 & 0 & 0\end{array}$

$\begin{array}{lll}0 & 0 & 0\end{array}$

$\begin{array}{lll}0 & 16 & 0\end{array}$

$\begin{array}{lll}0 & 0 & 0\end{array}$

$\begin{array}{lll}0 & 0 & 0\end{array}$

$96112 \quad 0$

$\begin{array}{lll}0 & 0 & 0\end{array}$

$\begin{array}{lll}144 & 48 & 16\end{array}$

$\begin{array}{lll}128 & 96 & 16\end{array}$

$\begin{array}{lll}432 & 320 \quad 0\end{array}$

$\begin{array}{lll}1344 & 32 & 0\end{array}$

$\begin{array}{lll}0 & 64 & 80\end{array}$

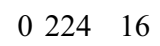

$0416 \quad 16$

$\begin{array}{lll}0 & 96 & 0\end{array}$

Habitat type

Tufa barriers

Lower lotic habitats

Mayfly taxa/Microhabitat

\begin{tabular}{lllllllllllllllllllll}
\hline NOB1 NOB2 & NOB3 & LB1 & LB2 & LB3 & KM1 & KM2 & KM3 & KR1 & KR2 & KR3 & PP1 & PP2 & PP3
\end{tabular}

(b) Tufa barriers and lower lotic habitats.

Baetidae juv.

Alainites muticus (Linnaeus, 1758)

Baetis sp. juv.

Baetis cf. nubecularis (Eaton, 1898)

Baetis rhodani (Pictet, 1843)

Centroptilum luteolum (Müller, 1776)

Procloeon pennulatum (Eaton, 1870)

Caenis sp. juv.

Caenis horaria (Linnaeus, 1758)

Ephemerellidae juv.

Serratella ignita (Poda, 1761)

Torleya major (Klapalek, 1905)

Ephemera danica Müller, 1764

Heptageniidae juv.

Ecdyonurus submontanus Landa, 1969

Rhithrogena braaschi Jacob, 1974

Leptophlebiidae juv.

Habrophlebia lauta Eaton, 1884

Paraleptophlebia submarginata

(Stephens, 1835)

Siphlonurus croaticus Ulmer, 1920

$\begin{array}{rrrrrrr}0 & 459 & 16 & 612 & 0 & 80 & 0 \\ 0 & 0 & 16 & 0 & 0 & 0 & 0 \\ 80 & 663 & 0 & 918 & 0 & 0 & 0 \\ 112 & 3417 & 16 & 4590 & 0 & 0 & 0 \\ 0 & 0 & 0 & 1377 & 0 & 0 & 16 \\ 272 & 459 & 256 & 0 & 432 & 16 & 16 \\ 0 & 0 & 0 & 0 & 0 & 0 & 0 \\ 16 & 0 & 0 & 0 & 0 & 16 & 0 \\ 16 & 0 & 48 & 918 & 192 & 16 & 0 \\ 0 & 0 & 0 & 0 & 0 & 0 & 0 \\ 16 & 0 & 0 & 0 & 0 & 0 & 0 \\ 224 & 612 & 0 & 0 & 0 & 0 & 0 \\ 1200 & 0 & 1120 & 0 & 1936 & 1552 & 16 \\ 0 & 0 & 0 & 0 & 0 & 0 & 0 \\ 0 & 0 & 0 & 0 & 0 & 0 & 0 \\ 0 & 0 & 0 & 0 & 0 & 0 & 0 \\ 0 & 5967 & 0 & 612 & 32 & 48 & 0 \\ 0 & 0 & 0 & 0 & 0 & 0 & 0 \\ 96 & 153 & 80 & 1836 & 0 & 0 & 0\end{array}$

$\begin{array}{rr}153 & 0 \\ 0 & 0 \\ 459 & 0 \\ 0 & 0 \\ 1989 & 0 \\ 0 & 0 \\ 0 & 0 \\ 0 & 0 \\ 0 & 0 \\ 0 & 0 \\ 0 & 0 \\ 0 & 0 \\ 0 & 32 \\ 0 & 0 \\ 0 & 0 \\ 0 & 0 \\ 0 & 32 \\ 0 & 0 \\ 0 & 48\end{array}$

$\begin{array}{rrr}160 & 918 & 80 \\ 0 & 0 & 0 \\ 64 & 0 & 16 \\ 0 & 0 & 0 \\ 576 & 1785 & 464 \\ 288 & 0 & 64 \\ 0 & 0 & 0 \\ 0 & 0 & 0 \\ 0 & 0 & 0 \\ 48 & 357 & 0 \\ 240 & 1989 & 208 \\ 16 & 0 & 0 \\ 800 & 0 & 512 \\ 0 & 0 & 0 \\ 0 & 0 & 0 \\ 0 & 0 & 0 \\ 0 & 0 & 0 \\ 0 & 0 & 0 \\ 0 & 0 & 0\end{array}$

$\begin{array}{rrr}1536 & 1020 & 128 \\ 0 & 0 & 0 \\ 7840 & 0 & 0 \\ 4414 & 0 & 0 \\ 1728 & 408 & 0 \\ 0 & 15198 & 1936 \\ 0 & 0 & 16 \\ 0 & 0 & 0 \\ 0 & 0 & 0 \\ 0 & 0 & 0 \\ 17360 & 2448 & 128 \\ 0 & 0 & 0 \\ 0 & 9486 & 976 \\ 0 & 0 & 0 \\ 0 & 0 & 0 \\ 0 & 102 & 0 \\ 48 & 1887 & 144 \\ 0 & 1224 & 224 \\ 0 & 208 & 320 \\ & & \\ 0 & 208 & 112\end{array}$




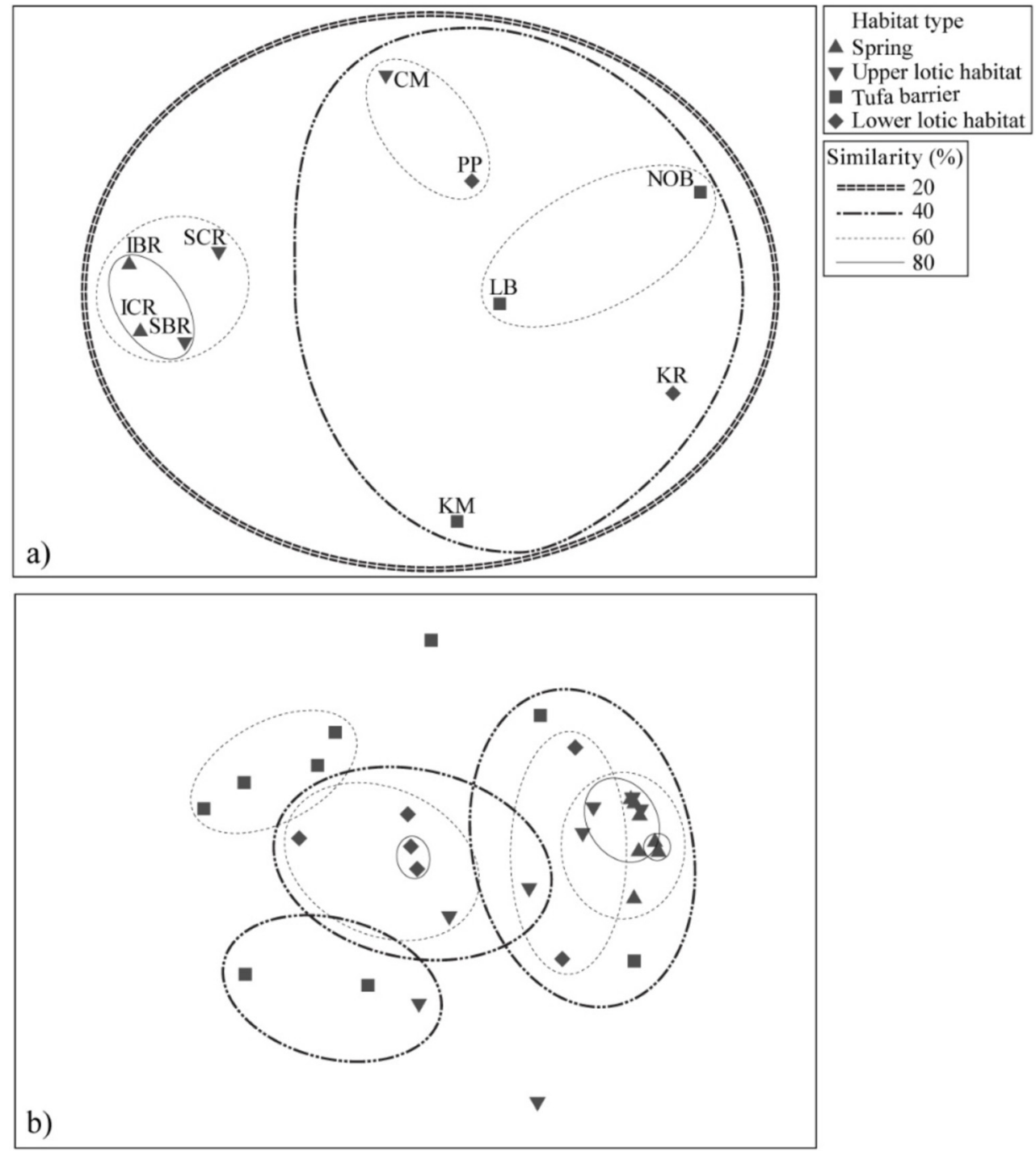

Fig. 2. NMDS analysis of the study sites in the different habitat types in Plitvice Lakes NP based on the composition of mayfly fauna shown (a) pooled per study site and (b) per microhabitat. Study sites: $\mathrm{IBR}=$ Bijela rijeka river spring, $\mathrm{SBR}=$ Bijela rijeka river upper reaches, $\mathrm{ICR}=$ Crna rijeka river spring, $\mathrm{SCR}=\mathrm{Crna}$ rijeka river middle reaches, $\mathrm{CM}=\mathrm{Crna}$ rijeka river lower reaches, $\mathrm{KR}=$ Korana river, $\mathrm{PP}=$ Plitvica stream, $\mathrm{KM}=$ Tufa barrier Kozjak-Milanovac, $\mathrm{LB}=$ Tufa barrier Labudovac, $\mathrm{NOB}=$ Tufa barrier Novakovića Brod.

also most likely resulted in a relatively low diversity of mayfly assemblages (e.g. Hrovat et al., 2009; Vilenica et al., 2016a, b). The results obtained from the mayfly fauna are in accordance with data obtained from physico-chemical analyses of the water. Our results clearly indicate differences in physicochemical water characteristics throughout Plitvice Lakes NP. As expected, the lowest variations were recorded in the springs and spring zones, where environmental conditions are stable regardless of stream type (Jones and Mulholland, 2000). On the other hand, sites situated downstream of the barrage-lake system, and sites at tufa barriers and in the lower lotic habitats, showed higher fluctuations in environmental factors. In accordance with the literature (e.g. Berner and Pescador, 1988; Bauernfeind and Soldán, 2012), the lowest mayfly species' richness was recorded in the springs and spring areas. Mayfly diversity is usually highest in meta- and hyporhithral stream sections (upper reaches) (Bauernfeind and Soldán, 2012). However, downstream sections of lower lotic habitats had the most diverse mayfly assemblages due to the rhithral character, more suitable environmental conditions (e.g. higher water temperature), a variety of available microhabitats and food resources (see also in Vilenica et al., 2014). Generally, tufa barriers were a less favourable habitat than the lower lotic habitats, which could be due to the more prominent fluctuations in oxygen concentrations, water temperature and available nutrients. On the other hand, tufa barriers were a more favourable habitat type than upper lotic habitats, due to the higher amount of organic matter. The barriers are situated between lakes, which is why they represent natural lake outlet habitats where organic matter accumulates, thus enhancing conditions for detritivorous insects such as mayflies (Obelić et al., 2005; Šemnički et al., 2012; Ivković et al., 2013a).

Similar to the previously investigated freshwater systems of the Dinaric Karst (Vilenica et al., 2016b), water temperature and $\mathrm{pH}$ were amongst the most important variables that determined mayfly assemblages and their distribution (e.g. Gerhardt, 1990; Moog, 2002; Petrin, 2011; Bauernfeind and Soldán, 2012). In addition, habitat type (springs, upper lotic habitats, tufa barriers and lower lotic habitats) and ammonium concentrations also played an important role. 


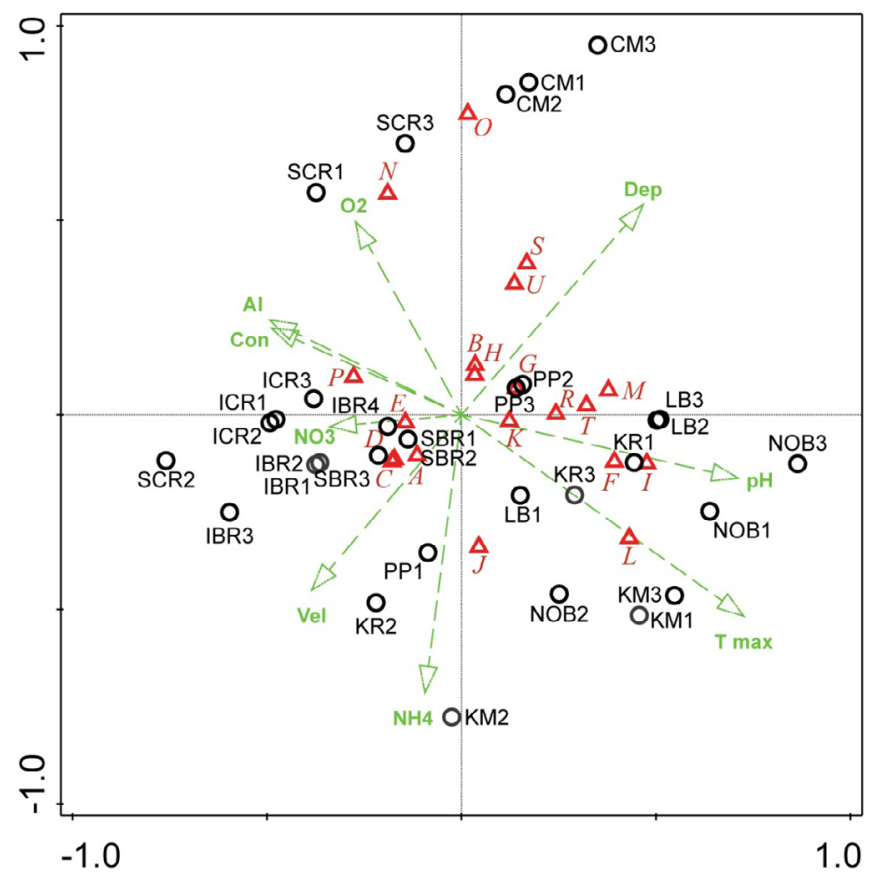

Fig. 3. F1 $\times$ F2 plane of CCA analysis showing 20 mayfly taxa, 10 study sites encompassing 31 microhabitats in Plitvice Lakes $\mathrm{NP}$ and nine selected environmental variables. Legend: Study sites (black circle symbols): $\mathrm{IBR}=$ Bijela rijeka river spring, $\mathrm{SBR}=$ Bijela rijeka river upper reaches, $\mathrm{ICR}=\mathrm{Crna}$ rijeka river spring, $\mathrm{SCR}=\mathrm{Crna}$ rijeka river middle reaches, $\mathrm{CM}=\mathrm{Crna}$ rijeka river lower reaches, $\mathrm{KR}=$ Korana river, $\mathrm{PP}=$ Plitvica stream, $\mathrm{KM}=$ Tufa barrier KozjakMilanovac, $\mathrm{LB}=$ Tufa barrier Labudovac, $\mathrm{NOB}=$ Tufa barrier Novakovića Brod. Environmental factors (green arrow symbols): $\mathrm{T}$ max $=$ maximum water temperature $\left({ }^{\circ} \mathrm{C}\right) ; \mathrm{O} 2=\mathrm{O}_{2} \quad\left(\mathrm{mgL}^{-1}\right)$; $\mathrm{pH}=\mathrm{pH}$ value; $\mathrm{Con}=$ Conductivity $\left(\mu \mathrm{S} \mathrm{cm}^{-1}\right) ; \mathrm{Al}=$ Alkalinity $\left(\mathrm{mg} \mathrm{L}^{-1} \mathrm{CaCO}_{3}\right)$; Vel = Water velocity $(\mathrm{cms}-1)$; Dep = Water depth $(\mathrm{cm}) ; \mathrm{NO} 3=$ Nitrates $\left(\mathrm{mg} \mathrm{L}^{-1}\right) ; \mathrm{NH} 4=$ Ammonium $\left(\mathrm{mg} \mathrm{L}^{-1}\right)$. Taxa (red triangle symbols): $A=$ juvenile Baetidae, $B=$ Alainites muticus, $C=$ juvenile Baetis sp., $D=$ Baetis $c f$. nubecularis, $E=$ Baetis rhodani, $F=$ Centroptilum luteolum, $G=$ Procloeon pennulatum, $H=$ juvenile Caenis sp., $I=$ Caenis horaria, $J=$ juvenile Ephemerellidae, $K=$ Serratella ignita,$L=$ Torleya major, $M=$ Ephemera danica, $N=$ juvenile Heptageniidae, $O=$ Ecdyonurus submontanus, $P=$ Rhithrogena braaschi, $R=$ juvenile Leptophlebiidae, $S=H a b-$ rophlebia lauta, $T=$ Paraleptophlebia submarginata, $U=$ Siphlonurus croaticus.

The NMDS analysis showed a grouping of mayfly assemblages according to habitat type (see also in Siegloch et al., 2014; Lencioni and Spitale, 2015), with a clear separation of upper lotic habitats from lower lotic habitats and tufa barriers. In addition to differences in the physico-chemical water properties, upper lotic habitats differed from tufa barriers and lower lotic habitats in the microhabitat composition. In the upper lotic habitats, microhabitats mainly consisted of pebbles, sand, angiosperms and bryophytes, while in tufa barriers and lower lotic habitats, pebbles/tufa, bryophytes on tufa, tufa with detritus and silt dominated.

Several of the recorded species showed a significant preference for habitat type. To date, larvae of $R h$. braaschi have been recorded in the rhithral sections (upper reaches) of brooks and smaller rivers lying at elevations from 600 to $1000 \mathrm{~m}$ (Bauernfeind and Soldán, 2012). The distribution of this species in Plitvice Lakes NP was in accordance with its known habitat preferences (Jacob, 1974; Vidinova, 2003; Bauernfeind and Soldán, 2012), in the springs and upper lotic habitats, at sites with a low and constant water temperature. On the other hand, our results indicate that tufa barriers are less favourable for the species, which should be investigated in more detail. The limnophilic (lentic) species C. horaria, predominantly inhabiting the lakes (Bauernfeind and Soldán, 2012), was recorded at the tufa barriers but in low abundance. As much higher abundances of this species were recorded in the surrounding lakes (Vilenica et al., 2014), low numbers of larval specimens at the tufa barriers are most likely the consequence of drift from upstream lakes (Sertić Perić et al., 2011). Two eurytopic and eurythermic species, C. luteolum and $S$. ignita, found most commonly in habitats with moderate $\left(<18^{\circ} \mathrm{C}\right)$ and warmer water $\left(\geq 18^{\circ} \mathrm{C}\right)$ (Schmidt-Kloiber and Hering, 2015), preferred the lower lotic habitats in Plitvice Lakes NP, where such conditions were recorded.

Considering their water temperature requirements, the majority of the mayfly species recorded in the current study were eurytherms (Schmidt-Kloiber and Hering, 2015), with the exception of the warm stenotherms $P$. pennulatum and C. horaria (Bauernfeind and Soldán, 2012; Schmidt-Kloiber and Hering, 2015). Accordingly, these two species were recorded only at sites with the highest water temperatures, namely the tufa barriers ( $\max$. temp. NOB $22.9^{\circ} \mathrm{C}$; LB $20.5^{\circ} \mathrm{C}$; $\mathrm{KM} 22.9^{\circ} \mathrm{C}$ ) and lower lotic habitats (max. temp. KR $19.8^{\circ} \mathrm{C}$; PP $15.4^{\circ} \mathrm{C}$ ). Several additional species recorded in the lower lotic habitats and tufa barriers were also correlated with higher water temperatures, such as the eurythermic S. ignita, two species preferring moderate water temperatures $\left(<18^{\circ} \mathrm{C}\right)$, Ephemera danica Müller, 1764 and Torleya major (Klapálek, 1905) (Kamler, 1965; Céréghino and Lavandier, 1998; Bauernfeind and Soldán, 2012; Schmidt-Kloiber and Hering, 2015), and B. cf. nubecularis. Since the taxonomic status of the latter species is unresolved, its ecological preferences cannot be compared.

Another environmental factor strongly influencing mayfly assemblages was $\mathrm{pH}$. Majority of mayfly species inhabit freshwaters with a neutral to alkaline $\mathrm{pH}$, whereas they are highly sensitive to low $\mathrm{pH}$ values (e.g. Gerhardt, 1990; Petrin, 2011). $\mathrm{pH}$ values of the karst streams and rivers usually range from 6.5 to 8.5 , due to the geological effects of karst substrate (Štambuk-Giljanović, 2005). In accordance with the recorded $\mathrm{pH}$ range (6.8-8.9), the majority of mayfly taxa recorded in our study preferred a neutral to alkaline environment (Jazdzewska and Górczynski, 1991; Schmidt-Kloiber and Hering, 2015), with $R h$. braaschi and $B$. rhodani inhabiting sites with a neutral $\mathrm{pH}$ and $C$. horaria, E. danica and T. major preferring sites with a more alkaline $\mathrm{pH}$.

Conductivity and alkalinity also had a strong influence on both diversity and abundance of mayflies in Plitvice Lakes NP, with e.g. B. rhodani (Dolisy and Dohet, 2003), Alainites muticus (Linnaeus, 1758) (López-Rodríguez et al., 2010) and $R h$. braaschi tolerating higher values and C. horaria, E. danica and T. major selecting sites with lower values.

The requirement for an adequate oxygen content in water is commonly high in mayflies (Bauernfeind and Soldán, 2012). Generally, oxygen concentrations in karst rivers fluctuate 
M. Vilenica et al.: Knowl. Manag. Aquat. Ecosyst. 2017, 418, 14

Table 4. Spearman's rank significant correlation coefficient $(R)$ for mayfly species and physico-chemical water properties in Plitvice Lakes NP. Sample size $(N)=366,{ }^{* * *} p<0.001,{ }^{* *} p<0.01, * p<0.05$.

\begin{tabular}{|c|c|c|c|c|}
\hline Species & Environmental factor & $R$ & $t(N-2)$ & $p$-Value \\
\hline \multirow[t]{3}{*}{ Alainites muticus } & Nitrate ions & -0.14 & -2.74 & $* *$ \\
\hline & Conductivity & 0.12 & 2.37 & $*$ \\
\hline & Alkalinity & 0.10 & 1.99 & $*$ \\
\hline \multirow[t]{4}{*}{ Baetis cf. nubecularis } & Water velocity & 0.31 & 6.31 & $* * *$ \\
\hline & Water depth & -0.25 & -4.91 & $* * *$ \\
\hline & Ammonium ions & 0.14 & 2.67 & $* *$ \\
\hline & Water temperature & 0.11 & 2.09 & $*$ \\
\hline \multirow[t]{6}{*}{ Baetis rhodani } & $\mathrm{pH}$ & -0.18 & -3.46 & $* * *$ \\
\hline & Conductivity & 0.30 & 5.99 & $* * *$ \\
\hline & Alkalinity & 0.27 & 5.41 & $* * *$ \\
\hline & Nitrate ions & 0.15 & 2.94 & $* *$ \\
\hline & Water velocity & 0.13 & 2.51 & $*$ \\
\hline & Water depth & -0.12 & -2.23 & * \\
\hline \multirow[t]{3}{*}{ Centroptilum luteolum } & Water velocity & -0.34 & -6.99 & $* * *$ \\
\hline & Water depth & 0.19 & 3.61 & $* * *$ \\
\hline & Oxygen concentration & -0.14 & -2.64 & $* *$ \\
\hline \multirow[t]{6}{*}{ Caenis horaria } & Conductivity & -0.19 & -3.69 & $* * *$ \\
\hline & Alkalinity & -0.18 & -3.44 & $* * *$ \\
\hline & Water temperature & 0.15 & 2.79 & $* *$ \\
\hline & $\mathrm{pH}$ & 0.15 & 2.81 & $* *$ \\
\hline & Nitrate ions & -0.11 & -2.02 & $*$ \\
\hline & Oxygen concentration & -0.12 & -2.34 & $*$ \\
\hline \multirow[t]{8}{*}{ Ephemera danica } & Water temperature & 0.18 & 3.51 & $* * *$ \\
\hline & Water velocity & -0.35 & -7.04 & $* * *$ \\
\hline & Water depth & 0.23 & 4.52 & $* * *$ \\
\hline & $\mathrm{pH}$ & 0.23 & 0.52 & $* * *$ \\
\hline & Conductivity & -0.24 & -4.73 & $* * *$ \\
\hline & Alkalinity & -0.24 & -4.77 & $* * *$ \\
\hline & Nitrate ions & -0.14 & -2.65 & $* *$ \\
\hline & Oxygen concentration & -0.12 & -2.39 & $*$ \\
\hline \multirow[t]{2}{*}{ Serratella ignita } & Water temperature & 0.14 & 2.74 & $* *$ \\
\hline & Water velocity & -0.13 & -2.58 & $*$ \\
\hline \multirow[t]{4}{*}{ Torleya major } & Conductivity & -0.19 & -3.83 & $* * *$ \\
\hline & Alkalinity & -0.18 & -3.46 & $* * *$ \\
\hline & $\mathrm{pH}$ & 0.17 & 3.21 & $* *$ \\
\hline & Water temperature & 0.11 & 2.05 & $*$ \\
\hline Ecdyonurus submontanus & Water depth & 0.13 & 2.57 & $*$ \\
\hline \multirow[t]{4}{*}{ Rhithrogena braaschi } & $\mathrm{pH}$ & -0.26 & -5.06 & $* * *$ \\
\hline & Conductivity & 0.29 & 5.94 & $* * *$ \\
\hline & Alkalinity & 0.29 & 5.72 & $* * *$ \\
\hline & Nitrate ions & 0.21 & 4.00 & $* * *$ \\
\hline
\end{tabular}


Table 4. (continued).

\begin{tabular}{|c|c|c|c|c|}
\hline Species & Environmental factor & $R$ & $t(N-2)$ & $p$-Value \\
\hline \multirow[t]{3}{*}{ Habrophlebia lauta } & Water velocity & -0.24 & -4.66 & $* * *$ \\
\hline & Water depth & 0.16 & 3.03 & $* *$ \\
\hline & Conductivity & 0.12 & 2.38 & $*$ \\
\hline \multirow[t]{2}{*}{ Paraleptophlebia submarginata } & Water velocity & -0.17 & -3.56 & $* * *$ \\
\hline & Water depth & 0.11 & 2.05 & $*$ \\
\hline \multirow[t]{4}{*}{ Siphlonurus croaticus } & Water velocity & -0.23 & -4.40 & $* * *$ \\
\hline & Water depth & 0.13 & 2.51 & $*$ \\
\hline & Alkalinity & 0.12 & 2.26 & $*$ \\
\hline & Ammonium ions & -0.12 & -2.27 & $*$ \\
\hline
\end{tabular}

between 10 and $12 \mathrm{mg} / \mathrm{L}$ (Štambuk-Giljanović, 2005). In the current study, the water was well oxygenated (average in the range $10.1-11.1 \mathrm{mg} / \mathrm{L}$ ) though several species, such as C. luteolum, E. danica and C. horaria, exhibited a correlation with lower concentrations of dissolved oxygen. These species usually inhabit slow-flowing or standing water bodies (Bauernfeind and Soldán, 2012; Schmidt-Kloiber and Hering, 2015), often associated with lower oxygen concentrations compared to fast flowing streams (Giller and Malmqvist, 1998; Wetzel, 2001). As such, they were generally more abundant in the downstream sections of lower lotic habitats, Plitvica stream and Korana river, on sandy substrates with lower water velocity.

Plitvice Lakes NP is an oligotrophic freshwater system (e.g. Habdija et al., 2004; Špoljar et al., 2007). However, several sites (springs and lower lotic habitats) exhibited slightly higher concentrations of nitrates and ammonium ions due to increased demands of tourism for waste disposal in recent decades (Petrik, 1961; Matoničkin and Pavletić, 1967). This may have had a positive effect on the algal growth (Fried et al., 2003) and quantity of food, making these sites more suitable habitats for a higher abundance and higher number of mayfly taxa. Nevertheless, the values of nitrates and ammonium could increase more in the near future. This should be taken in account while protecting this valuable karst river system and its communities. Two species were correlated with ammonium concentrations, B. cf. nubecularis with higher and Siphlonurus croaticus Ulmer, 1920 with lower values, indicating higher and lower tolerance, respectively. The potential sensitivity of $S$. croaticus to ammonium should be further studied.

Mayfly assemblages were also influenced by water velocity, and the majority of species preferred habitats with the higher water speed. This was not surprising since large number of mayfly species inhabit well oxygenated running waters with moderate to high current, having a certain preference for specific water velocity (Schmedtje and Colling, 1996; Bauernfeind et al., 2002; Menetrey et al., 2008; Bauernfeind and Soldán, 2012). Water velocity also influences the distribution of organic matter (Habdija et al., 2004; Miliša et al., 2006), which is another factor having an impact on mayfly distribution (e.g. Williams and Hynes, 1974; Fjellheim, 1996; Habdija et al., 2004). In the studied hydrosystem, water velocity was inversely proportional to water depth, therefore the rheo- to limnophilic E. danica and Paraleptophlebia submarginata (Stephens, 1835) and limno- to rheophilic Habrophlebia lauta Eaton, 1884 preferred sites with greater water depth and lower water velocity. On the other hand, B. cf. nubecularis and B. rhodani preferred sites with lower water depth and greater velocity. Thus, the highest diversity and/or abundance of mayflies in Plitvice Lakes NP were recorded at study sites with greater water velocity and lower water depth (e.g. Tufa barrier Novakovića-Brod) and with higher $\mathrm{pH}$ and water temperature (e.g. lower lotic habitats), which is in accordance with the habitat preferences of most mayfly species (e.g. Bauernfeind and Humpesch, 2001; Bauernfeind and Soldán, 2012).

In conclusion, the mayfly assemblages of Plitvice Lakes NP clearly reflected the high heterogeneity of the investigated karst hydrosystem, where their significant preferences for certain habitat types and physico-chemical water properties were recorded. Due to the specific abiotic factors, such as relatively low annual water temperature, high alkalinity and low productivity (e.g. Habdija et al., 2004; Špoljar et al., 2007), herbivorous and detritivorous mayflies encounter poorer food resources (Bauernfeind and Soldán, 2012). This leads to relatively low species richness in the karst system of Plitvice Lakes NP (Hrovat et al., 2014; Vilenica et al., 2016a). Nevertheless, some interesting faunistic aspects were recorded, such as taxonomically intriguing species of Baetis from the alpinus group, which presents intermediate morphological characteristics between Baetis alpinus Pictet, 1845 and B. nubecularis (see also in Vilenica et al., 2014, 2015). Future investigations should focus on a detailed taxonomic revision of B. alpinus group. Furthermore, species with a wide (e.g. B. rhodani, C. horaria, S. ignita), patchy (e.g. E. submontanus, S. croaticus) and Balkan (e.g. Rh. braaschi) distribution (Bauernfeind and Soldán, 2012; Schmidt-Kloiber and Hering, 2015) were identified. Since the presence or absence of certain mayflies was strongly influenced by the physicochemical water properties, this study confirmed that they are a powerful tool as descriptors of their environment. Future studies should include systematic ecological study throughout the entire Plitvice Lakes NP area, encompassing the lakes and a wider range of microhabitats. Due to the very sensitive bio-dynamics of tufa deposition in this hydrosystem, long-term monitoring of the inhabiting species should be also conducted. Despite the specifics are in the hydrology of 
the Dinaric Karst system, the current study showed that the standard methodology for mayfly assemblage monitoring is applicable.

Acknowledgements. The comprehensive macroinvertebrate study at Plitvice Lakes NP was conducted on the basis of permissions of Ministry of Environmental and Nature Protection of Republic of Croatia (RN: 532-08-02-1/7-06-3; 532-0802-1/7-06-3). The authors would like to thank Andreja Komljenović, Martina Krbavčić, Sanja Žalac, Bruno Polak and Matija Simac for their essential assistance during field surveys. Many thanks to Ivančica Krulik, Mirjana Jelenčić and Sanja Sviben for assistance in sorting the collected material. We also thank Dr. Anita Belančić for literature loan. The study is a result of projects No. 119-1193080-1206 (PL: M. Kučinić) and No. 119-1193080-3076 (PL: M. Kerovec) supported by the Croatian Ministry of Science, Education and Sports. Many thanks to Prof. Dr. Mladen Kerovec for financial support, and Dr. Ana Previšić, Dr. Helen Barber James, Dr. Jasna Lajtner and Dr. Andreja Brigić for their comments and advice. We would also thank the reviewers for their useful comments and suggestions that markedly improved this manuscript.

\section{References}

Allan JD, Castillo MM. 2007. Stream ecology: structure and function of running waters. Dordrecht: Springer, $436 \mathrm{p}$.

Bãnãrescu PM. 2004. Distribution pattern of the aquatic fauna of the Balkan Peninsula. In: Griffith H, Kryštufek B, Reed JM, eds. Balkan biodiversity pattern and process in the European hotspot. Dordrecht: Kluwer Academic Publishers, pp. 203-219.

Bauernfeind E, Humpesch UH. 2001. Die Eintagsfliegen Zentraleuropas - Bestimmung und Ökologie. Verlag Naturhistorisches Museum Wien: 1-239.

Bauernfeind E, Moog O. 2000. Mayflies (Insecta: Ephemeroptera) and the assessment of ecological integrity: a methodological approach. Hydrobiologia 422: 71-83.

Bauernfeind E, Soldán T. 2012. The mayflies of Europe (Ephemeroptera). Ollerup: Apollo Books, 781 p.

Bauernfeind E, Moog O, Weichselbaumer P. 2002. Ephemeroptera. Part III. In: Moog O, ed. Fauna Aquatica Austriaca. Wasserwirtschaftkataster, Bundesministerium für Land und Forstwirtschaft, Umwelt und Wasserwirtschaft, Wien, 1-24.

Berner L, Pescador ML. 1988. The mayflies of Florida - Revised Edition. Gainesville: University Presses of Florida, 415 p.

Bonacci O, Jelin J. 1988. Identification of a karst hydrological system in the Dinaric karst (Yugoslavia). Hydrolog Sci J 33: 483-497.

Bonacci O. 2009. Karst landscape ecohydrology. In: Proceedings of International Symposium on Water Management and Hydraulic Engineering, Ohrid, pp. 781-790.

Bonacci O, Pipan T, Culver D. 2008. A framework for karst ecohydrology. Environ Geol 56: 891-900.

Bonacci O, Željković I, Galić A. 2013. Karst rivers' particularity: an example from Dinaric karst (Croatia/Bosnia and Herzegovina). Environ Earth Sci 70: 963-974.

Brittain JE, Sartori M. 2003. Ephemeroptera (Mayflies). In: Resh VH, Cardé R, eds. Encylopedia of insects. Amsterdam: Academic Press, pp. 373-380.

Céréghino R, Lavandier P. 1998. Influence of hypolimnetic hydropeaking on the distribution and population dynamics of Ephemeroptera in a mountain stream. Freshwater Biol 40: 385-399.
Choudhary J, Singh SN, Singh S. 2014. Physico-chemical and biological parameters of the three rural ponds of Sasaram of Bihar. Int J Appl Sci Biotechno 2: 206-210.

Clarke KR, Gorley RN. 2006. PRIMER V6: User Manual/Tutorial. Plymouth: Primer-E.

Dolisy D, Dohet A. 2003. The use of Ephemeroptera to assess aquatic biodiversity in the Luxembourgish rivers. In: Gaino E, ed. Research update on ephemeroptera and plecoptera. Perugia: University of Perugia, pp. 299-303.

Dufrêne M, Legendre P. 1997. Species assemblages and indicator species: the need for a flexible asymmetrical approach. Ecol Monogr 67: 345-366.

Fjellheim A. 1996. Distribution of benthic invertebrates in relation to stream flow characteristics in a Norwegian river. Regul River 12: 263-271.

Fried S, Mackie B, Nothwehr E. 2003. Nitrate and phosphate levels positively affect the growth of algae species found in Perry Pond. Tillers 4: 21-24.

Gerhardt A. 1990. Effects of subacute doses of Cadmium on pHstressed Leptophlebia marginata (L.) and Baetis rhodani Pictet (Insecta: Ephemeroptera). Environ Pollut 6: 29-42.

Giller PS, Malmqvist B. 1998. The biology of streams and rivers. New York: Oxford University Press, 304 p.

Habdija I, Primc-Habdija B, Belinić I. 1994. Functional community organization of macroinvertebrates in lotic habitats of the Plitvice lakes. Acta Hydroch Hydrob 22: 85-92.

Habdija I, Primc-Habdija B, Matoničkin R, Kučinić M, Radanović I, Miliša M, Mihaljević Z. 2004. Current velocity and food supply as factors affecting the composition of macroinvertebrates in bryophyte habitats in karst running water. Biologia 59: 577-593.

Hrovat M, Urbanič G, Sivec I. 2009. Community structure and distribution of Ephemeroptera and Plecoptera larvae in lowland karst rivers in Slovenia. Aquat Insect 31: 343-357.

Hrovat M, Urbanič G, Sivec I. 2014. Aquatic insects along environmental gradients in a karst river system: a comparative analysis of EPT larvae assemblage components. Int Rev Hydrobiol 99: $1-14$.

Ivković M, Plant A. 2015. Aquatic insects in the Dinarides: identifying hotspots of endemism and species richness shaped by geological and hydrological history using Empididae (Diptera). Insect Conserv Divers. doi: 10.1111/icad.12113.

Ivković M, Kesić M, Mihaljević Z, Kúdela M. 2013a. Emergence patterns and ecological associations of some haematophagous blackfly species along an oligotrophic hydrosystem. Med Vet Entomol 28: 94-102.

Ivković M, Gračan R, Horvat B. 2013b. Croatian aquatic dance flies (Diptera: Empididae: Clinocerinae and Hemerodromiinae): species diversity, distribution and relationship to surrounding countries. Zootaxa 3686: 255-276.

Jacob U. 1974. Rhithrogena braaschi n. sp., eine neue Heptageniidae aus Bulgarien (Insecta, Ephemeroptera). Entomol Nachr Ber 18: 167-173.

Jazdzewska T, Górczynski A. 1991. Les Ephéméropteres des rivières qui franchissent la zone marginale du Roztocze Central. In: AlbaTercedor J, Sánchez-Ortega A, eds. Overview and strategies of Ephemeroptera and Plecoptera. Florida: The Sandhill Crane Press, pp. 263-270.

Jones JB, Mulholland PJ. 2000. Streams and ground waters. San Diego: Academic Press, 425 p.

Kamler E. 1965. Thermal conditions in mountain waters and their influence on distribution of Plecoptera and Ephemeroptera larvae. Ekol Pol 13: 1-38. 
Lencioni V, Spitale D. 2015. Diversity and distribution of benthic and hyporheic fauna in different stream types on an alpine glacial floodplain. Hydrobiologia 751: 73-87.

López-Rodríguez MJ, Tierno de Figueroa JM, Alba-Tercedor J. 2010. Comparative Study of the Nymphal biology of two coexisting species of mayflies (Insecta: Ephemeroptera) in a Mediterranean stream in Southern Europe. Int Rev Hydrobiol 95: 58-71.

Makjanić B. 1958. O klimi užeg područja Plitvičkih jezera. Hrvatski geografski glasnik (in Croatian): 33-34.

Matoničkin I, Pavletić Z. 1961. Biljni i životinjski svijet na sedrenim slapovima jugoslavenskih krških voda. Biološki glasnik (in Croatian) 14: 105-127.

Matoničkin I, Pavletić Z. 1967. Hidrologija potočnog Sistema Plitvičkih jezera i njegove ekološko-biocenološke značajke. Krš Jugoslavije, JAZU, Zagreb (in Croatian) 5: 83-126.

Menetrey N, Oertli B, Sartori M, Wagner A, Lachavanne JB. 2008 Eutrophication: are mayflies (Ephemeroptera) good bioindicators for ponds? Hydrobiologia 597: 125-135.

Mičetić Stanković V, Jäch MA, Kučinić M. 2015. Annotated checklist of Croatian riffle beetles (Insecta: Coleoptera: Elmidae). Nat Croat 24: 93-109.

Mihevc A, Zupan-Hajna N, Prelovšek M. 2010. Case study from the Dinaric karst of Slovenia. In: Mihevc A, Prelovšek M, ZupanHajna N, eds. Introduction to the Dinaric karst. Postojna: Karst Research Institute, pp. 49-66.

Miliša M, Habdija I, Primc-Habdija B, Radanović I, Matoničkin Kepčija R. 2006. The role of flow velocity in the vertical distribution of particulate organic matter on moss-covered travertine barriers of the Plitvice Lakes (Croatia). Hydrobiologia 553: 231-243.

Moog O. 2002. Fauna Aquatica Austriaca, Edition 2002. Wassserwirtschaftskataster, Bundesministerium für Land- und Forstwirtschaft, Umwelt und Wasserwirtschaft, Vienna.

Obelić B, Horvatinčić N, Barešić J, Briansó Babinka S, Suckow A. 2005. Anthropogenic pollution in karst lake sediments (Croatia). In: Özkul M, Yaĝiz S, Jones B, eds. Proceedings of 1 st International Symposium on Travertine, 179-186.

Petrik M. 1961. Temperatura i kisik Plitvičkih jezera. JAZU, Zagreb, 1-37 (In Croatian).

Petrin Z. 2011. Species traits predict assembly of mayfly and stonefly communities along pH gradients. Oecologia 167: 513-524.

Popijač A, Sivec I. 2009. Diversity and distribution of stoneflies in the area of Plitvice Lakes National Park and along the Mediterranean river Cetina (Croatia). Aquat Insect 31: 731-742.

Previšić A, Kerovec M, Kučinić M. 2007. Emergence and composition of Trichoptera from karst habitats, Plitvice Lakes Region, Croatia. Int Rev Hydrobiol 92: 61-83.

Previšić A, Walton C, Kučinić M, Mitrikeski PT, Kerovec M. 2009. Pleistocene divergence of Dinaric Drusus endemics (Trichoptera, Limnephilidae) in multiple microrefugia within the Balkan Peninsula. Mol Ecol 18: 634-647.

Previšić A, Schnitzler J, Kučinić M, Graf W, Ibrahimi H, Kerovec M, Pauls SU. 2014. Microscale vicariance and diversification of Western Balkan caddisflies linked to karstification. Freshwater Sci 33: 250-262.

Sánchez-Fernández D, Abellán P, Velasco J, Millán A. 2004. Selecting areas to protect the biodiversity of aquatic ecosystems in a semiarid Mediterranean region. Aquat Conserv 14: 465-479.

SchmedtjeU, Colling M. 1996. Ökologische Typisierung der aquatischen Makrofauna. Inf ber Bayer Landesamtes Wasserwirtsch 4: 1-543.
Schmidt-Kloiber A, Hering D. 2015. www.freshwaterecology.info an online tool that unifies, standardises and codifies more than 20,000 European freshwater organisms and their ecological preferences. Ecol Indic 53: 271-282.

Šemnički P, Previšić A, Ivković M, Čmrlec K, Mihaljević Z. 2012. Tufa barriers from a caddisfly's point of view: streams or Lake Outlets? Int Rev Hydrobiol 97: 465-484.

Sertić Perić M, Miliša M, Matoničkin Kepčija R, Primc-Habdija B, Habdija I. 2011. Seasonal and fine-scale spatial drift patterns in tufa-depositing barrage hydrosystem. Fund Appl Limnol 178: $131-145$.

Siegloch AE, Suriano M, Spies M, Fonseca-Gessner A. 2014. Effect of land use on mayfly assemblages structure in Neotropical headwater streams. An Acad Bras Ciênc 86(4): 1735-1747. doi:10.1590/0001-3765201420130516.

Šikić Z. 2007. Plan upravljanja Nacionalnog parka Plitvička Jezera [Plitvice Lakes National Park Management Plan]. Croatian Ministry of Culture. ISBN 978-953-6240-83-8. Retrieved 31 March 2015 (In Croatian).

Špoljar M, Primc-Habdija B, Habdija I. 2007. Transport of seston in the karstic hydrosystem of the Plitvice Lakes (Croatia). Hydrobiologia 579: 199-209.

Srdoč D. 1985. Procesi taloženja kalcita u krškim vodama s posebnim osvrtom na Plitvička jezera. Krš Jugoslavije 11: 4-6.

Štambuk-Giljanović N. 2005. The quality of water resources in Dalmatia. Environ Monit Assess 104: 235-267.

Stilinović B, Božičević S. 1998. The Plitvice Lakes - a natural phenomenon in the middle of the Dinaric karst in Croatia. Eur Water Manage 1: 15-24.

Ter Braak CJF, Šmilauer P. 1998. Canoco for windows: software for canonical community ordination (version 4.02). Wageningen, The Netherlands: Centre for Biometry Wageningen, CPRODLO.

Vannote RR, Minshall GW, Cummins KW, Sedell JR, Cushing CE. 1980. The river continuum concept. Can J Fish Aquat Sci 37: $130-137$.

Vidinova Y. 2003. Contribution to the study of mayfly fauna (Ephemeroptera) in Bulgaria. In: Gaino E, ed. Research update on Ephemeroptera and Plecoptera, Proceedings of the International Joint Meeting, 2001, Perugia (Italy), pp. 159-163.

Vilenica M, Gattolliat J-L, Ivković M, Kučinić M, Mičetić Stanković V, Mihaljević Z, Sartori M. 2014. The mayfly fauna (Insecta, Ephemeroptera) of the Plitvice Lakes National park, Croatia. Nat Croat 23: 349-363.

Vilenica M, Gattolliat J-L, Mihaljević Z, Sartori M. 2015. Croatian mayflies (Insecta, Ephemeroptera): species diversity and distribution patterns. ZooKeys 523: 99-127.

Vilenica M, Previšić A, Kučinić M, Gattolliat JL, Sartori M, Mihaljević Z. 2016a. Distribution and autecology of mayflies (Insecta, Ephemeroptera) in a Mediterranean river in the Western Balkans. Entomol News 126: 19-35.

Vilenica M, Previšić A, Ivković M, et al.2016b. Mayfly (Insecta: Ephemeroptera) assemblages of a regulated perennial Mediterranean river system in the Western Balkans. Biologia 71: 1038-1048.

Wetzel RG. 2001. Limnology: lake and river ecosystems, 3rd ed. San Francisco, New York, London: Academic Press (An Elsevier Science Imprint), $1006 \mathrm{p}$.

Williams DD, Hynes HBN. 1974. The occurrence of benthos deep in the substratum of a stream. Freshwater Biol 4: 233-256. 